YEARBOOK
of ANTITRUST
and REGULATORY
STUDIES
www.yars.wz.uw.edu.pl

Peer-reviewed scientific periodical, focusing on legal and economic issues of antitrust and regulation. Creative Commons Attribution-No Derivative Works 3.0 Poland License.

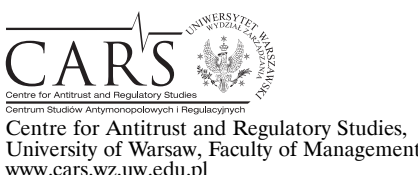

www.cars.wZ.uw.edu.pl

\title{
The Interaction of Public and Private Enforcement of Competition Law in Lithuania
}

\author{
by \\ Rimantas Antanas Stanikunas* and Arunas Burinskas**
}

\section{CONTENTS}

I. Introduction

II. Modernisation of private antitrust enforcement by the Damages Directive

III. Rules and case law applicable to private antitrust enforcement in Lithuania

IV. Challenges concerning the quantification of harm and the establishment of causality

V. Private enforcement and the leniency programme

VI. Conclusions

\section{Abstract}

This paper provides a study of the interaction between public and private enforcement of Lithuanian antitrust law. The study refers to the Damages Directive. It has been found that private enforcement depends greatly on public enforcement of competition law. Therefore, their compatibility and balance are of great importance to antitrust policy. The Lithuanian NCA prioritises cases where an economic effect on competition does not have to be proven. This creates uncertainty about the outcome of private enforcement cases. Private enforcement in Lithuania is also in need of detailed rules on the identification of harm and causality. The analysis reveals how challenging it can be to estimate and prove harm or a causal link in private enforcement cases. Support from the NCA is therefore exceedingly needed. Moreover, even though the use of the leniency programme helps, it remains insufficient to solve the problem of under-deterrence. However, measures introduced by the Damages Directive do not make the leniency programme safe.

* Professor at the Vilnius University; e-mail: r.stanikunas@glimstedt.lt.

** Ph.D. candidate at the Vilnius University; e-mail: burinskas.arunas@gmail.com. 


\section{Résumé}

Cet article fournit une étude concernant l'interaction entre l'application publique et privée du droit de la concurrence en Lituanie. Létude se réfère à la Directive relative aux actions en dommages. Il constate que l'application privée du droit de la concurrence dépend largement de son application publique. En conséquence, leur compatibilité et l'équilibre sont de grande importance pour la politique de la concurrence. L'autorité de la concurrence lituanienne donne le priorité aux affaires dans lesquels un effet économique sur la concurrence ne doit pas être prouvé. Cela crée une incertitude concernant le résultat des actions en dommages. Lapplication privée du droit de la concurrence en Lituanie a également besoin de règles détaillées sur l'identification du préjudice et la causalité. Comme l'analyse effectuée révèle, il peut être très difficile d'estimer un préjudice ou et de prouver un lien de causalité dans les affaires concernant l'application privée du droit de la concurrence. C'est pourquoi, le soutien de la part de l'autorité de la concurrence lituanienne est extrêmement nécessaire. En outre, même si l'utilisation du programme de clémence peut être évalué positivement, elle reste insuffisante pour résoudre le problème de la sous-dissuasion. Toutefois, les mesures introduites par la Directive n'assurent pas la sécurité du programme de clémence.

Key words: antitrust damages actions; private enforcement of antitrust rules; competition law; leniency programme.

JEL: K23; K42.

\section{Introduction}

The recently adopted EU Directive on Antitrust Damages Actions ${ }^{1}$ (hereafter, Damages Directive) is aimed at facilitating and boosting private antitrust enforcement. The Directive incorporates different measures that aim to remove the main obstacles that plaintiffs face when bringing private actions. It also tries to strike a balance between public and private enforcement. The Directive contains measures that pretend to protect efficient public antitrust enforcement through leniency programmes. Therefore, this analysis starts with a short review of the Directive.

In the EU, private litigation normally follows a decision of a National Competition Authority (hereafter, NCA). Private enforcement heavily depends

1 Directive 2014/104/EU of the European Parliament and of the Council of 26 November 2014 on certain rules governing actions for damages under national law for infringements of the competition law provisions of the Member States and of the European Union, OJ L 349, 05.12 .2014 , p. 1 . 
therefore on public enforcement of competition law. Their compatibility and balance are thus of great importance to antitrust policy.

Lithuania's Competition Law ${ }^{2}$ (hereafter, LCL) and the TFEU comprise the core of the legislation regulating antitrust policy in Lithuania. The purpose of the LCL is to protect and secure the freedom of fair competition in the country, and to harmonise Lithuanian and European law on competition relations. The Lithuanian NCA - the Competition Council of Lithuania - is responsible for the execution of national competition policy. The application of the LCL is reviewed by administrative courts. In Lithuania, private antitrust cases are resolved before civil courts (courts of general competence).

The basic principle behind such liability in Lithuanian law is that every person has the duty to act in such a way as not to cause damage to another person and, accordingly, that any harm caused as a result of a illegal action must be compensated by the person responsible for the claim being made by the injured party (a general law doctrine). Broadly, the conditions for tort liability are similar to those found in most European legal systems.

This paper reviews Lithuanian legislation related to private antitrust enforcement and contains a survey of the few national cases that have appeared in this area so far. Both reflect the current lack of detailed regulation on the quantification of harm and the establishment of causality in Lithuania. Uncertainty about the outcome of private enforcement cases does not facilitate private damages actions.

The following section shows how the Lithuanian NCA can play the role of Amicus Curiae (a friend of the court). It is revealed how challenging it can be to provide an estimation of the harm, as well as to actually prove the harm and the existence of a causal link in private enforcement cases. The role of the NCA role in helping with these issues could thus be far greater.

The leniency programme helps, but remains insufficient to solve the problem of under-deterrence. The Damages Directive introduced therefore some measures that facilitate antitrust damages actions. However, these measures undermine the leniency programme placing greater liability on leniency applicants.

The paper contains an introduction followed by five individual sections. The second section outlines the main features of the Damages Directive, including a short description of its aims and key improvements concerning private antitrust enforcement. The third section presents a brief description of Lithuanian private antitrust enforcement rules and case law. The fourth section investigates the challenges that surround the issue of quantifying harm and establishing a causal link in private enforcement cases. It is shown here

2 Competition Law of Republic of Lithuania, VZ No. VIII-1099, 23.03.1999. Available at: http://www3.lrs.lt/pls/inter3/dokpaieska.showdoc_1?p_id=1040736 (accessed 21.10.2015). 
how a NCA's infringement decision can be helpful with those issues. The fifth section considers how the new rules affect the leniency programme. The last part contains conclusions.

\section{Modernisation of private antitrust enforcement by the Damages Directive}

Private enforcement refers to the decentralised application of competition rules by individuals through private litigation before national courts of EU Member States, typically seeking damages. It provides an alternative to public enforcement, which involves the top-down application of competition law by the European Commission (hereafter, EC or Commission) or NCAs against infringing parties ${ }^{3}$.

Articles 101 and 102 TFEU impose freestanding prohibitions on certain forms of anticompetitive behaviour that are enforceable by the public hand of the Commission or NCAs, as well as privately by individuals that have suffered losses. The orthodoxy within EU law is to view public and private enforcement as 'complementary' and, mostly, mutually reinforcing 4 .

Pursuant to the case law of the Court of Justice (hereafter, CJ), citizens have the right to seek damages for cartel behaviours that caused them a loss, by virtue of the direct effect of Article 101 TFEU. While follow-on damages actions enable citizens to enforce their Treaties-based rights, these actions are purely about compensation - they do not serve public enforcement. On the other hand, in considering the need to encourage private enforcement of Article 102 TFEU, the importance of facilitating swift injunctive relief (to the greatest extent possible) cannot be overstated. Damages actions for exclusionary practices are extremely difficult to bring to fruition in a reasonable time frame, and they raise complex questions based in an economic analysis 5 .

The rationale for private antitrust enforcement is to empower individual consumers that have suffered distinct and quantifiable harm,

3 N. Dunne, 'The Role of Private Enforcement within EU Competition Law' (2014) 36 University of Cambridge Faculty of Law Research Paper.

${ }^{4}$ Communication from the Commission on quantifying harm in actions for damages based on breaches of Article 101 or 102 of the Treaty on the Functioning of the European Union (OJ C 167, 13.06.2013, p. 19).

5 F. Louis, 'Promoting private antitrust enforcement: remember article 102' [in:] Ph. Lowe, M. Marquis (eds.), European Competition Law Annual 2011: Integrating Public and Private Enforcement of Competition Law-Implications for Courts and Agencies, Bloomsbury Publishing, Oxford 2014, p. 85-94. 
attributable directly to an antitrust breach, to obtain compensation for their losses.

As soon as both enforcement systems are implemented in a given jurisdiction, Rubinfeld argues that the key question is how to harmonise both systems in order to minimise costs and avoid problems of under- or over deterrence ${ }^{6}$.

To date, private antitrust enforcement remains underdeveloped within the EU. It is this 'absence' that the Commission sought to address by formulating the Damages Directive. According to the EC, the objective of public enforcement, premised upon the use of administrative fines, is deterrence. This encompasses both specific deterrence by sanctioning the undertaking concerned, and general deterrence by scaring other undertakings away from breaching competition rules. At the same time, the Commission maintains that compensation is the primary objective of private enforcement - to 'repair the harm' caused by the breach. Nonetheless, benefits of deterrence and greater antitrust compliance are also envisaged as a result of private enforcement ${ }^{7}$.

According to the Commission ${ }^{8}$, the Damages Directive will help citizens and companies claim damages if they are victims of antitrust infringements based on Article $101 \& 102$ TFEU, such as cartels or abuses of dominance. The primary goals of the Directive are identified as follows:

(i) the Directive should facilitate access to evidence by antitrust victims, which they need to prove the damage they had suffered, and give them more time to make their claims; the right for victims of antitrust infringements to be compensated for the harm suffered has been acknowledged by the CJ; however, due to national procedural obstacles, only a few victims are currently being compensated; the Directive is also to reduce the wide divergence in national rules concerning antitrust damages currently present in the EU;

(ii) the Directive should facilitate a more efficient enforcement of EU antitrust rules overall: (a) it will fine-tune the interplay between private and public enforcement; (b) at the same time it will preserve the attractiveness of tools used by NCAs, in particular, leniency programmes and settlement procedures.

Pursuing such goals, the Commission introduced a set of improvements that have to be implemented into all Member States' legal regimes. They include: (i) national courts can order companies to disclose evidence when victims claim compensation, courts will ensure, however, that such disclosure orders are

${ }^{6}$ D. Rubinfeld, 'An Empirical Perspective on Legal Process: Should Europe Introduce Private Antitrust Enforcement?' [in:] P. Nobel, M. Gets (eds.), New Frontiers of Law and Economics, Schulthess Juristische Medien, Zurich 2006, p. 141-148.

7 N. Dunne, op. cit.

8 EC, 'Antitrust: Commission welcomes Council adoption of Directive on antitrust damages actions' (2014), http://europa.eu/rapid/press-release_IP-14-1580_en.htm (accessed 04.09.2015). 
proportionate, and that confidential information is duly protected; (ii) a final decision of a NCA finding an infringement will automatically constitute proof of that breach before courts of the same Member State where the infringement occurred; (iii) victims will have at least one year to claim damages once an infringement decision by a competition authority has become final; (iv) if an infringement has caused price increases, and these have been 'passed on' along the distribution chain, those who ultimately suffered harm will be entitled to claim compensation; (v) consensual settlements between victims and infringing companies will be made easier by clarifying their interplay with court actions - this will allow a faster and less costly resolution of disputes.

The Commission seeks therefore to facilitate the restoration of justice making it easier to recover damages suffered by clients and customers of antitrust infringers. However, it is also ultimately supposed to deter infringers by encouraging private litigation as well as to relief the heavy bureaucratic burden that rested on the European system since its inception ${ }^{9}$.

$\mathrm{K}$. Hüschelrath and H. Schweitzer noticed that despite the EC's good intentions, both to facilitate private damages actions and remove obstacles for victims of anticompetitive conduct, the Damages Directive still leaves many important issues unanswered.

First of all, on the private enforcement side, it is still unclear:

(i) how should the harm caused by antitrust infringements be quantified? How to assess what would have happened in the absence of the infringement? Which methods are legally acceptable, which methods are feasible?

(ii) how should the disclosure of evidence within private antitrust enforcement be organised?

(iii) how should the passing-on defence be treated in private enforcement suits?

Secondly, concerning the interaction of public and private enforcement, several critical questions remain unanswered including:

(i) is it still justified to calculate fines according to the same principles that were applicable when private enforcement remained dormant?

(ii) how do 'best practices' differ for expert economic testimony by competition authorities, and how relevant are they for effective and efficient public and private enforcement of competition law? ${ }^{10}$

${ }^{9} \mathrm{EC}$, White paper on modernisation of the rules implementing articles 85 and 86 of the EC Treaty - Commission programme No. 99/027 (OJ C 132, 12.05.1999, p. 1).

${ }^{10} \mathrm{~K}$. Hüschelrath, H. Schweitzer, 'Public and Private Enforcement of Competition Law in Europe - Introduction and Overview' [in:] K. Hüschelrath, H. Schweitzer (eds.), Public and Private Enforcement of Competition Law in Europe. Legal and Economic Perspectives. ZEW Economic studies Vol. (48), Springer, Berlin - Heidelberg 2014, p. 1-8. 
Answers to these questions impact issues of civil litigation which are still under development. Therefore, this paper attempts to make a contribution to this ongoing discussion looking in more detail into the quantification of harm and the establishment of causality.

\section{The rules and case law applicable to private antitrust enforcement in Lithuania}

Audzevičius states ${ }^{11}$ that the LCL and the TFEU contain the core legislation regulating antitrust policy in Lithuania. The purpose of the LCL is to protect and secure the freedom of fair competition in the country, and to harmonise Lithuanian and EU law regulating competition relations. The NCA is the designated institution for the execution of the competition policy of the Lithuanian State. The application of the LCL is reviewed by administrative courts. Private antitrust cases are resolved before Lithuanian civil courts (courts of general competence). There are no specialised courts (or even specialised court divisions) committed to the resolution of antitrust cases. However, the Vilnius Regional Administrative Court has the sole jurisdiction to hear antitrust cases as the court of $1^{\text {st }}$ instance.

The legal basis for private antitrust enforcement in Lithuania is provided by the LCL together with rules of the new Lithuanian Civil Code (hereafter, LCC $)^{12}$ and the Lithuanian Code of Civil Procedure (hereafter, LCCP) ${ }^{13}$ introduced in 2001 and 2003 respectively.

The basic principle behind such liability in Lithuanian law is that every person has the duty to act in such a way as not to cause damage to another person and, accordingly, that any harm caused as a result of a illegal action must be compensated by the person responsible for the claim being made by the injured party (a general law doctrine). The conditions for tort liability are generally similar to those found in most other European legal systems.

Article 43 LCL establishes that economic entities that violate this Law must compensate for damage caused to other economic entities or natural and legal persons in accordance with the procedure laid down by the LCC and LCCP.

11 R. Audzevičius, 'Lithuania' [in:] I.K. Gotts (ed.), The Private Competition Enforcement Review, Law Business Research Ltd 2014, p. 242-253.

12 Lithuanian Civil Code, VZ No. VIII-1864, 06.09.2000. Available at: http://www3.lrs.lt/pls/ inter3/oldsearch.preps2?Condition1 $=107687 \&$ Condition2 $=($ accessed 21.10.2015).

13 Lithuanian Code of Civil Procedure, VZ No. IX-743, 28.02.2002. Available at: http://www3. lrs.lt/pls/inter3/oldsearch.preps2?Condition $1=107687 \&$ Condition $2=($ accessed 21.10 .2015$)$. 
Article 47 LCL allows for two type of actions: 1) actions on the termination of illegal activities or, 2) actions on the compensation for damages incurred on the grounds of an antitrust infringement (of Articles 101 or 102 TFEU or the LCL) that has violated legitimate interests of the plaintiff. In most cases the latter is submitted as a follow-on action, which is pursuant to the finding of an antitrust infringement by the Lithuanian NCA. However, Article 47 LCL allows victims also to prove the infringement and request damages without the NCA having investigated this particular matter. However, not a single final court decision has yet been issued in Lithuania that satisfied the claims of a private claimant that applied to the court directly.

The above provision of the LCL corresponds to Article 1 of the Damages Directive that allows anyone who has suffered harm caused by an antitrust infringement committed by an undertaking (or by an association of companies) to effectively exercise its right to claim full compensation for that harm from the infringer.

Article 6.245 LCC allows any person to claim damages if it can be proved that a set of liability conditions have been met. They include: the infringement of the law by the defendant (Article 6.246 LCC); harm suffered by the plaintiff (Article 6.249 LCC); causality between the wrongdoing and the harm (Article 6.247 LCC). The fault of the infringer is presumed if an infringement has been proved according to Article 6.246 LCC. Article 6.263 LCC establishes also the main tort law rule which, among other things, constitutes a presumption of the wrongdoing by the defendant where the harm of the plaintiff is proven.

According to Article 6.249 LCC, damages cover the amount of direct expenses related to the injury (direct losses) and the income not received due to the infringement (indirect losses). The claimant has to prove the size of the damages claimed. Interest for damages is also awarded. The LCC sets the minimum interest rates at an annual rate of either 5 or 6 per cent, depending on whether the case at hand is civil or commercial respectively. The claimant may also seek compensation for extra reasonable expenses (such as those suffered to prevent the need for greater damages, expenses to evaluate damages or collect them without litigation) ${ }^{14}$. Moreover, Lithuanian courts are entitled to award damages based on their own estimation and discretion if the plaintiff can prove causality but has failed to prove the exact amount of damages suffered. Estimating the level of damages based on the defendants' profits gained from the illegal actions is also an apt evaluation method.

Article 178 LCCP allows and obligates the claimants to prove their statements while Article 199 LCCP enables the claimant to ask the court to order the disclosure of relevant data (written evidence) from the defendant

14 Ibidem. 
or third parties. However, the plaintiff must prove the relevance of such information and the fact that the defendant, or a third person, actually hold it.

These rules correspond to Article 8 of the Damages Directive which gives claimants the right to request the court to order the defendant, or a third party, to disclose relevant evidence in their possession.

As R. Audzevičius reports ${ }^{15}$, practice shows that the Lithuanian NCA prefers investigating cases where an economic effect on competition does not have to be proven (in other words, abuse of dominance cases are not prioritised). As a result, case law concerning abuses is expected to decline. However, the amount of investigations into hard-core cartels is to grow - investigating horizontal agreements seems to be a priority for the Lithuanian NCA.

From 2000 to the summer of 2014, the Lithuanian NCA investigated 44 cases of restrictive agreements (Article 5 LCL). Most of these are cases that impose least burden of proof on the NCA (horizontal price-fixing and marketsharing agreements).

In theory, follow-on litigation should benefit from earlier public efforts, as it eases costs and results in higher awards making follow-on actions more attractive. Given that the decisions of the Lithuanian NCA have probative value; individuals should prefer to lodge a complaint to the Lithuanian NCA to investigate suspected anti-competitive practices $^{16}$.

However, avoiding hard-to-prove cases by the Lithuanian NCA translates into a much heavier burden of proof placed on the plaintiffs in private damages actions cases. It is possible that this is the main reason why follow-on actions have not yet seen an increase domestically, even though the NCA has adopted a number of infringement decisions already. As J. Malinauskaite confirms, public enforcement is predominant in Lithuania in the antitrust field with barely any private actions to date ${ }^{17}$. As L. Prosperetti argues, a claimant in a follow-on action does not enjoy a substantial advantage over a claimant in a standalone action, as in most cases he will need to supply adequate proof of the harm suffered. Although antitrust authorities usually find agreements having an anticompetitive object, this is not sufficient to establish harm. Even when illegal exclusionary conduct (abuse of dominance) has been established, its effects may be difficult to disentangle from the results of [parallel] legitimate conduct. Moreover, the competitors of the dominant infringer may have been

15 R. Audzevičius, 'Lithuania' [in:] I.K. Gotts (ed.), The Private Competition Enforcement Review, Law Business Research Ltd 2014, p. 242-253.

16 J. Malinauskaite, 'Private enforcement of competition law in Lithuania: a story of underdevelopment' (2013) 3 Global Competition Litigation Review 123-135.

17 Ibidem. 
affected to varying degrees by its illicit behaviour. Thus, in most cases, the claimant will need to prove both causation and harm ${ }^{18}$.

In the Lithuanian case, it appears that fulfilling the burden of proof can be a deterrent to private enforcement. As Woods et al. reveal, this is because it can be very difficult for claimants to amass sufficient evidence to prove their claim. It can be difficult to attribute loss specifically to the defendant's behaviour, rather than to other factors such as a general economic slowdown or even the claimant's own business strategy ${ }^{19}$. A short analysis of Lithuanian case law on private damages actions can confirm such fear.

Two cases have been uncovered here where private damages actions had actually been resolved by a final decision of Lithuanian courts. Both of them are follow-on cases, initiated after the adoption of a respective resolution by the NCA. The claims in UAB Siauliu tara v. AB Stumbras was partially satisfied as the Court of Appeal awarded a much smaller amount of damages than actually claimed (case No. 2A-41/2006). The claim in UAB Klevo lapas $v$ $A B$ Orlen Lietuva was ultimately rejected by the Supreme Court of Lithuania (case No. 3K-3-207/2010) due to the absence of a causal link between the antitrust infringement and the damages incurred by the claimant. In both cases, plaintiffs asked for an award of damages after an abuse of dominance had been identified by the NCA.

In the first case, UAB 'Šiauliu tara' lodged a complaint to the NCA alleging that the defendant SPAB 'Stumbras' (while enjoying a dominant position in the strong alcoholic beverages market between 2000-2002) applied discriminatory conditions to equivalent marketing service agreements with certain undertakings, including the claimant. Hence, it placed Šaulių tara, which was unable to sell the products at a lower price, at a competitive disadvantage. The claim was based on the NCA's decision that declared that the actions of Stumbras constituted a breach of Article 9(3) LCL (now it is Article 7(3) LCL). In the final decision, the Court of Appeal of Lithuania stated that an infringement decision by the NCA has probative value in Lithuania and that the defendant abused its dominant position. Although the court agreed that the claimant was entitled to compensation, it stated that Šiauliu tara had failed to prove the entire amount of the requested damages. The Court reduced, therefore, the amount of damages granted. The main focus of this case was on the calculation of damages. The court stressed that

18 L. Prosperetti, 'Proving and quantifying antitrust damages: an economic perspective' (2008) 10(3) Mercato Concorrenza Regole 527-564.

19 D. Woods, A. Sinclair, D. Ashton, 'Private enforcement of Community competition law: modernisation and the road ahead' (2004) 2 Competition policy newsletter 31-37. 
the claimant must prove indirect damages, such as loss of income, and that they should be realistic rather than just probable ${ }^{20}$.

In this case, the plaintiff claimed damages for two types of losses: 1) that it did not receive certain discounts that the dominant firm had offered to other competitors; 2) that this caused the claimant a loss of profits. The courts awarded those damages suffered by the plaintiff (loss of income) that could be calculated in accordance with executed business transactions. However, the courts rejected the claim concerning damages that might have been suffered because of sales loss due to the infringement.

In the second case, upon request of Klevo lapas, the NCA initiated proceedings against $\mathrm{AB}$ 'Mazeikiu nafta' and concluded that the latter held a dominant position in certain gasoline and diesel fuel markets. By taking advantage of its unilateral decisive influence in those markets, it fixed dissimilar purchase conditions for its oil products for similar agreements with different companies. By so doing, Mazeikiu nafta abused its dominant position.

Similarly to the first case, the courts rejected the claim for damages that might have been suffered because of sales loss due to the infringement. However, the court refused here also to award damages that could be calculated in accordance with executed business transactions. They did so, on the ground that the plaintiff obtained benefits of equal size from the postponement of the payments (the damages were calculated as a loss of the plaintiff's profit). It shall be noted that the facts of the case did not show if the benefits that the plaintiff obtained were directly from, or due to the defendant's infringement. It thus seems that the Supreme Court rejected this part of the claim without a clear legal background. It is interesting to consider what the judgment would have said instead, if the plaintiff had realized its right to demand profits received by a liable person due to the infringement as damages according Article 6.249 LCC.

As this case shows, the decision of the NCA is not binding upon the court under Lithuanian law. This creates the risk that an abuse needs to be proven all over again by the claimant in a private case. This should soon change thanks to the Damages Directive that makes the final decision of an NCA binding upon national courts of the same Member State. This case is also an excellent example illustrating another major issue in this context: proving a causal link between the abuse (here, price discrimination) and the losses suffered (here, bankruptcy). In the reviewed case, the Supreme Court found that the plaintiff would have gone bankrupt anyway, so no damages could be obtained ${ }^{21}$.

20 J. Malinauskaite, 'Private enforcement of competition law in Lithuania: a story of underdevelopment' (2013) 3 Global Competition Litigation Review 123-135.

21 G. Monti, P.L. Parcu, European Networking and Training for National Competition Enforcers (ENTRANCE 2012). Selected Case Notes (May 2014), Robert Schuman Centre for Advanced Studies Research Paper No. RSCAS, 68, San Domenico di Fiesole 2014. 
In both cases, the calculation of damages was quite easy, but it still did not guarantee the full success of the claim. Supreme Court Judge J. Stripeikiene noted that Lithuanian law does not yet contain any requirements to disclose information, and that no guidelines for the calculation of damages have been established yet ${ }^{22}$.

\section{Challenges concerning the quantification of harm and the establishment of causality}

The above review of Lithuanian private antitrust enforcement and the Damages Directive's modernisation of this field, reveal that the quantification of damages and the establishment of causality remain a challenge in legal cases and not just for their participants but also for judges and even experts. Therefore, the Lithuanian NCA can play the role of Amicus Curiae (a friend of the court) helping with these issues.

Further arguments will show that the analysis of demand, which is needed in the market definition stage of competition proceedings, cannot be avoided when estimating harm and establishing the causal link either. Therefore, market definitions provided in the NCA's decisions would help claimants save money and time in private enforcement cases.

Tort law provides the general conceptual framework for the analysis of damages and causation. It defines the standards of proof, the basic tests for proving causation and for estimating damages, the rules on the burden of proof, and on access to information. Tort law does not offer substantive economic principles for such analysis however. It leaves economic arguments subject to the free consideration of evidence by judges. An economic interpretation is thus required to adapt the general legal framework for an economic analysis ${ }^{23}$ - such interpretation should thus be consistent with legal rules.

Private enforcement of antitrust damages critically hinges upon proof that an antitrust violation caused damage. Existing research narrowly focuses on quantifying damages, but proving causation goes far beyond quantification. Strict legal requirements must be observed. To address causation adequately, an integrated legal and economic approach is necessary. Traditional tort law examines, for each transaction, whether an antitrust violation caused damages with near certainty. This quasi-deterministic approach offers a seemingly unequivocal solution for assessing causation. However, cases as complicated as

22 J. Stripeikiene, 'Klevo Lapas v. ORLEN Lietuva' [in:] G. Monti, P.L. Parcu, op. cit.

${ }^{23}$ H.A. Abele, G.E. Kodek, G.K. Schaefer, 'Proving Causation in Private Antitrust Cases' (2011) 7(4) Journal of Competition Law and Economics 847-869. 
private antitrust damages cannot be decided by this methodological approach. By contrast, economic methods for proving causation (and quantification of harm) use statistical tools ${ }^{24}$.

From an economic point of view, collusion describes a situation where prices on a specific antitrust market (or markets) are raised or attempted to be raised, through direct or indirect communication between competitors, above a level that would have emerged without such communication. From a legal perspective explicit (but not tacit) collusion is prohibited. Proving damages suffered from such collusion is a complex endeavour. This definition highlights the fact that the focus of most damages calculations rests on estimating the price increase encountered by customers (rather than quantity or quality effects that generate much less attention in legal cases). When carrying out a damages calculation, this definition also highlights the need to first define antitrust markets - at least to some extent - in order to assess the affected volume. Finally, it stresses the importance of coming-up with a robust estimation of price levels which would have existed without the cartel agreement, the counterfactual, or 'but-for' price ${ }^{25}$.

The Commission issued a Practical guide on quantifying harm in actions for damages ${ }^{26}$. It provides therein some practical guidance on mathematical and econometrical methods that might be useful when quantifying harm, establishing causality, or even an infringement of antitrust law itself. Those methods include: interpolation, which provides the theoretical calculation of missing data; extrapolation is useful for forecasts based on data retrieved from past periods; regression analysis provides statistical techniques that help investigate the relationship between some variables; econometric modelling covers mathematical models that simulate demand and/or behaviour of market rivals.

This paper follows the categorisation of these methods put forward by most commentators in relevant literature ${ }^{27}$ :

- 'before and after' (ex post) approaches compare prices during the alleged cartel period with prices before the cartel agreement was reached and/or after the cartel's breakdown (reference here is to the 'during and after

24 Ibidem.

25 W. Friederiszick, L.H. Röller, 'Quantification of harm in damages actions for antitrust infringements: insights from German cartel cases' (2010) 6(3) Journal of Competition Law and Economics 595-618.

${ }^{26}$ Commission (EU), 'Staff Working Document - Practical Guide - Quantifying Harm in Action for Damages Based on Breaches of Articles 101 or 102 of the Treaty on the Functioning of the European Union', SWD (2013) (205) (Strasbourg, 11 June 2013) (Quantification Guide), paras 166-71.

27 Ibidem. 
approach' if no cartel-free period before the infringement took place is available);

- 'yardstick' approaches (in the narrower sense) compare the price in the cartelised region with prices in other geographic regions that are not affected by the cartel (regional benchmark). Specific challenges here centre on accounting for differences in the various regions and excluding indirect effects of the cartel, for example, the umbrella effect if neighbouring regions are used as benchmarks. As it turns out, cases based on a yardstick approach often tend to fail as the courts are easily convinced that no effective yardstick exists;

- a 'cost-based' approach constructs the 'but-for' price 'bottom up' by measuring the relevant costs of the affected product and adding a reasonable profit margin (which would emerge under normal market conditions). However, these methods do not seem very credible in practice because at the heart of their analysis lies a cost determination which is, in itself extremely difficult to achieve;

- simulations (theoretical modelling) are closely related to 'costbased' approaches as they often requires some cost information. This methodology uses however an explicit model of competition, which is used to 'simulate' the profit margins. In addition to data on costs, simulations require thus also information on market structure and demand (such as demand elasticities) ${ }^{28}$.

Accuracy remains a problem with all of these methods. Their application to the facts of specific legal cases can provide 'true results on average' that do not necessarily hold true for each specific transaction.

However, judges generally prefer the first, most simple and practical method. Hence, 'before and after' methods are very commonly employed by civil courts to estimate the amount of contractual and tort liability, and should thus be regarded as the prime candidate for antitrust damage estimation. These methods are based on the construction of a hypothetical income statement of the claimant, which should not reflect any effect arising from the antitrust breach. Civil courts have solid experience across Europe in the application of these methods.

The inclusion of the 'before and after' analysis of the relevant NCA's decision would thus be very helpful for preparing damages actions by victims.

As it was mentioned before, Lithuanian courts are entitled to award damages based on their own estimation and discretion provided the plaintiff can prove causality but cannot prove the exact amount of its own damages.

${ }^{28}$ L. Prosperetti, 'Antitrust Damages in Europe: An Economic Perspective' [in:] E.A. Raffaelli (ed.), Antitrust between EC Law and National Law: 7 Conference, 18-19 May 2006, Bruylant, Bruxelles 2007, p. 335-352. 
It means that an exact quantification of the size of damages is usually not required by law, and would often pose an impossible task. Hence, estimation of damages does not pose a big issue - the challenge is to prove them.

Lithuanian courts adopt a flexible causal link criterion - illegal actions do not lead to, but influence the damage by a sufficient degree (decision of the Supreme Court, case No. 3K-3-53-2010). In an antitrust law approach, this means that causation aims to clarify whether some illegal behaviour (of the cartel members or an entity abusing its dominant position) was instrumental in inflicting damage upon the plaintiff (customer). It has to be ruled out that the damage was caused by other factors ${ }^{29}$.

In the first stage, courts apply a test of conditio sine qua non (equivalent causation theory) and determine the actual causal connection - whether harmful consequences would result in the absence of the unlawful act. A key legal test for assessing causation is the 'but-for' test. The latter examines whether damages would not have occurred without the antitrust violation. Hence, a hypothetical scenario without an antitrust violation must be considered. The key challenge here is to prove causation to the requisite legal standards.

In the second stage, courts establish a legal causal link - they decide whether the legal consequences are not too remote from the allegedly unlawful conduct. A key role here is played by the rule of the defendant's ability to predict the consequences of his illegal actions (the standard of a reasonable person must be applied here to decide if the given consequences could be foreseen; if the answer is no, the legal consequences are considered to be too remote).

So, causation of the defendant's act for the damage has to be proved to a high degree of certainty. For that reason, the burden of proof lies with the plaintiff and this means, first, collecting evidence. For a plaintiff, it is all the more difficult to meet this burden because antitrust infringers typically have much more information about the violation than outside parties. This informational asymmetry makes it harder for plaintiffs to provide sufficient proof. As it was mentioned before, the LCCP includes the right to order evidence from the defendant and third parties. However, such evidence shall be identified in advance. And here lies a problem. In antitrust cases much of the key evidence necessary to prove a case for antitrust damages is often concealed and, being held by the defendant or by third parties, it is usually not known to the claimant in sufficient detail ${ }^{30}$.

In many antitrust cases, it can be difficult for plaintiffs to establish which transactions were directly or indirectly affected by an antitrust violation, and which remained unaffected. Stochastic causation obviates the need to draw

${ }^{29}$ H.A. Abele, G.E. Kodek, G.K. Schaefer, op. cit.

30 Ibidem. 
such sharp distinctions as it suffices to examine the overall effect exercised by a group of transactions. Under this concept, the plaintiff would only have to show that some damage was caused by the hazardous activity to a certain group of customers. The requirement to provide proof with near certainty for each individual case is thereby relaxed. Since excessive claims are to be avoided, compensation is shared among all members of the group that suffered damages in proportion to the probability of having been affected ${ }^{31}$.

The passing-on defence should be noted also. When the price of an input rises, companies will try to shift the price increase to their own buyers. It can be proved that, in general, the ability to pass-on an increase in the input price will mainly depend on the given elasticity of demand. If the price increase was generated by a cartel, defendants in antitrust case must thus prove not only that passing-on actually took place, but also the size of the passing-on effect, which will depend upon demand elasticities (and other factors, such as the reaction of competitors). This means that defendants are to use one of the aforementioned methods designed to quantify harm and establish causality. So, all of the abovementioned issues remain more or less the same too. It will thus not be easy to fulfil such a heavy burden of proof. In practice therefore, the passing-on defence will rarely be successful ${ }^{32}$.

The legal principles of proving causation are too general to be directly applicable to a private antitrust case. Hence, an economic interpretation of these principles is required. First, damages have to be properly defined in terms of the actual prices and quantities affected by the antitrust violation and the hypothetical prices and quantities in a scenario without an antitrust violation. Next, based upon these definitions, the question can be raised as to how to prove differences in prices and quantities between the actual and the hypothetical scenarios so as to establish the existence of damages.

As mentioned, the 'but-for' test lies at the heart of causation analysis in tort law. Provided some damage has occurred, the goal of this test is to ensure that the damage cannot be explained by factors other than the actions of the defendant. In the case of excessive prices, it must be shown that high prices were due to an antitrust violation, rather than other price determinants. Conducting such an analysis requires a thorough understanding of the relationship between prices and their determinants, including the potential impact of the antitrust violation. A thorough understanding of price determinants is thus essential as both legal and economic assessments of causation focus on this question ${ }^{33}$.

Therefore, as H.A. Abele argues, the concept of average systematic damages has important implications for the burden of proof. First of all, it should

\footnotetext{
31 Ibidem.

${ }^{32}$ L. Prosperetti, op. cit.

33 H.A. Abele, G.E. Kodek, G.K. Schaefer, op. cit.
} 
be noted that, by its very nature, the average systematic price component relies upon a statistical concept. It does so to make sense of the multitude of different prices in the data and to account for the impact of other price factors. Even if complete data on all transactions in the market was available, it would still be necessary to resort to statistical procedures to analyse the data. Second, also due to the statistical nature of the concept, average systematic price effects can be computed from a representative sample of transactions ${ }^{34}$. Yet such analysis opens the way to approximations and estimations.

These issues related to the economic analysis of damages and causality affects the standard of proof. As mentioned, experts rely on the theoretical evaluation of harm and causality because of lack of relevant information. Moreover, this issue persists in almost all cases. Assistance from the NCA could thus be very helpful here. According to Lithuanian civil procedure rules, the NCA shall assist the court by providing those of its conclusions on the case which would be helpful in the determination of the quantum of damages and the causal link. On the order of the court, the NCA shall provide relevant evidence (the case file).

All these arguments can support the aforementioned opinion expressed by the Supreme Court Judge J. Stripeikienè whereby additional requirements concerning information disclose and extra guidelines on the calculation of damages need to be established in Lithuania. It is suggested here that this is of a matter of high importance, especially considering that Article17 of the Damages Directive states clearly that: 'the Member States shall ensure that neither the burden nor the standard of proof required for the quantification of harm renders the exercise of the right to damages practically impossible or excessively difficult'.

\section{Private enforcement and the leniency programme}

L. Prosperetti asserts that even though the use of the leniency programme helps, it remains insufficient to solve the problem of under-deterrence. Yet if cartel members knew beforehand that, if discovered, they will have to disgorge all their cartel profits as damages (and lose their reputation) as well as pay a fine, joining the cartel would become less appealing ${ }^{35}$. As to the cartels, the basic model of collusion is based on so-called incentive constraints. It reveals that collusion depends on the total payoff received if companies collude by comparison to the profit each of them may generate in an optimal deviation

34 Ibidem.

35 L. Prosperetti, op. cit. 
scenario. Collusion is sustainable if the collusive payoff exceeds the benefits achieved when a company deviates ${ }^{36}$. Clearly, a decrease of expected profits from the collusive practice due to the rising risk of damages actions (because of more effective private enforcement rules) makes collusion less sustainable. This means, decreasing incentives to collude.

Leniency programmes increase, perhaps substantially, the probability of detection, but the imposed fines are insufficient. It is thus expected that private antitrust enforcement increases the costs of colluding companies and, in turn, also decreases their incentives to apply for leniency ${ }^{37}$.

However, the Commission asserts that measures introduced in the Damages Directive will preserve the attractiveness of leniency programmes. The Directive includes measures that should help not to deter companies from cooperating with NCAs including:

(i) self-incriminating statements shall be exempted from evidence disclosure; however, limitations on the disclosure of proof should not prevent NCAs from publishing their decisions, and this exemption applies only to voluntary self-incriminating statements; the Directive ensures the right of injured parties to retain sufficient alternative means how to obtain access to relevant evidence to prepare their actions for damages;

(ii) an immunity recipient shall be relieved from joint liability for the entire harm, any compensation it must provide vis-a-vis co-infringers cannot exceed the amount of damages caused to its own direct or indirect purchasers or, in the case of buying cartels, its direct or indirect providers; responsibility for other entities should not exceed its relative responsibility for the harm caused by the cartel; full liability to an immunity recipient shall be applied only when full compensation from other infringers is not available.

As stated by the CJ in Donau Chemie, absolute protection for certain documents is incompatible with the primary law principle of effectiveness; it is also problematic to privilege successful leniency applicants at the expense of injured parties. Some commentators suggest that the best solution would be to privilege members of cartels who receive immunity from fines in relation to their co-infringers by giving them the right to full contribution from their co-infringers ${ }^{38}$.

${ }^{36}$ M. Motta, Competition policy: theory and practice, Cambridge University Press, Cambridge 2004, p. 159-161, 193-202.

37 L. Prosperetti, op. cit.

38 Ch. Kersting, 'Removing the Tension Between Public and Private Enforcement: Disclosure and Privileges for Successful Leniency Applicants; (2014) 5(1) Journal of European Competition Law \& Practice 2-5. 
In practice, discovering cartels is a hard task for NCAs. This is a very expensive and time-consuming activity. However, NCAs are short of money and staff. It is particularly true for small, poorer EU countries, such as the Lithuanian Republic, with a NCA that disposes of less funding and lower staffing than some of its larger counterparts. It is thus necessary to invest precious resources to discover cartels, while their shortage lowers the possibility of detecting and proving collusive outcomes. Leniency helps save the sparse public resources - since companies bring evidence to the NCA directly, considerable costs in the prosecution stage are saved. As mentioned before, such evidence is useful in private enforcement cases.

The view of most authors has to be supported that asserts that the implementation of the Damages Directive is going to diminish the detection of cartels due to a fall in the number of leniency applications ${ }^{39}$.

\section{Conclusions}

The orthodoxy within EU law is to view public and private enforcement of Articles 101 and 102 TFEU as 'complementary' and, mostly, mutually reinforcing. Across the EU, private litigations normally follows an infringement decision of a NCA. Hence, private antitrust enforcement heavily depends in EU Member States on their public enforcement practice. Their compatibility and balance are thus of great importance to antitrust policy.

The review of Lithuanian legislation and case law relating to private antitrust enforcement shows the need for the introduction of more detailed rules on the identification of harm and causality. Uncertainty about the outcome of private enforcement cases does not facilitate private damages actions. For the last fifteen years, the Lithuanian NCA has investigated 44 cases of restrictive agreements (under Article 5 LCL) but only a few of them have resulted in damages actions, and only one of them was partially successful.

Investigations in cases where an economic effect on competition has to be proven (inter alia, abuses of a dominant position) are not a priority in Lithuania. Therefore, the claimant in a follow-on action does not enjoy a substantial advantage and bears a heavier burden of proof.

Decisions of the Lithuanian NCA are still not legally binding in civil cases - so far they only serve as prima facie written evidence only. If the court fails to confirm the decision of the NCA, claimants must bear the burden of proof

\footnotetext{
39 L. Prosperetti, op. cit.
} 
of the illegal act. However, the implementation of the Damages Directive into the Lithuanian legal regime will solves this issue.

The paper reveals how challenging it can be to estimate and prove harm or a causal link in private enforcement cases. It would thus be very helpful to include the most popular 'before and after' analysis in the NCA's decisions. Market definitions provided in relevant NCA's decisions would help claimants save time and money in private enforcement cases. Demand analysis is needed for both market definition and the estimation of harm and causation. According civil procedure rules, the Lithuanian NCA shall assist the court by providing those of its conclusions on the case which would be helpful in the determination of the quantum of damages and the causal link. On the order of the court, the NCA shall provide relevant evidence.

Although leniency helps, it is still insufficient to solve the problem of underdeterrence. Therefore, the Damages Directive introduced some measures that facilitate damages actions against infringers. However, these measures undermine leniency programmes because they place greater liability on leniency applicants.

\section{Literature}

Abele H.A., Kodek G.E., Schaefer G.K., 'Proving Causation in Private Antitrust Cases' (2011) 7(4) Journal of Competition Law and Economics.

Audzevičius R., 'Lithuania' [in:] I.K. Gotts (ed.), The Private Competition Enforcement Review, Law Business Research Ltd 2014.

Dunne N., 'The Role of Private Enforcement within EU Competition Law' (2014) 36 University of Cambridge Faculty of Law Research Paper.

Friederiszick W., Röller L.H., 'Quantification of harm in damages actions for antitrust infringements: insights from German cartel cases’ (2010) 6(3) Journal of Competition Law and Economics.

Hüschelrath K., Schweitzer H., 'Public and Private Enforcement of Competition Law in Europe - Introduction and Overview' [in:] K. Hüschelrath, H. Schweitzer (eds.), Public and Private Enforcement of Competition Law in Europe. Legal and Economic Perspectives, ZEW Economic Studies Vol. (48), Springer, Berlin - Heidelberg 2014.

Kersting Ch., 'Removing the Tension Between Public and Private Enforcement: Disclosure and Privileges for Successful Leniency Applicants' (2014) 5(1) Journal of European Competition Law \& Practice.

Louis F., 'Promoting private antitrust enforcement: remember article 102' [in:] Ph. Lowe, M. Marquis (eds.), European Competition Law Annual 2011: Integrating Public and Private Enforcement of Competition Law-Implications for Courts and Agencies, Bloomsbury Publishing, Oxford 2014.

Malinauskaite J., 'Private enforcement of competition law in Lithuania: a story of underdevelopment' (2013) 3 Global Competition Litigation Review. 
Monti G., Parcu P.L., European Networking and Training for National Competition Enforcers (ENTRANCE 2012). Selected Case Notes (May 2014), Robert Schuman Centre for Advanced Studies Research Paper No. RSCAS, 68, San Domenico di Fiesole 2014.

Motta M., Competition Policy: Theory and practice, Cambridge University Press, Cambridge 2004.

Pais S.O., Piszcz A., 'Package on Actions for Damages Based on Breaches of EU Competition Rules: Can One Size Fit All?' (2014) 7(10) Yearbook of Antitrust and Regulatory Studies.

Prosperetti L., 'Antitrust Damages in Europe: An Economic Perspective' [in:] E.A. Raffaelli (ed.), Antitrust between EC Law and National Law: 7 Conference, 18-19 May 2006, Bruylant, Bruxelles 2007.

Prosperetti L., 'Proving and quantifying antitrust damages: an economic perspective' (2008) 10(3) Mercato Concorrenza Regole.

Rubinfeld D., 'An Empirical Perspective on Legal Process: Should Europe Introduce Private Antitrust Enforcement?' [in:] P. Nobel, M. Gets (eds.), New Frontiers of Law and Economics, Schulthess Juristische Medien, Zurich 2006.

Stripeikiene J., 'Klevo Lapas v. ORLEN Lietuva' [in:] G. Monti, P.L. Parcu (eds.), European Networking and Training for National Competition Enforcers (ENTRANCE 2012). Selected Case Notes. Selected Case Notes (May 2014). Robert Schuman Centre for Advanced Studies Research Paper No. RSCAS, 68, San Domenico di Fiesole 2014.

Woods D., Sinclair A., Ashton D., 'Private enforcement of Community competition law: modernisation and the road ahead' (2004) 2 Competition policy newsletter. 